\title{
Częstość istotnych związków wysokości i masy ciała z cechami tułowia wśród 4-6-letnich dzieci obojga płci i z dwóch różnych środowisk
}

\section{The frequency of significant relationships between body weight and height and parameters of trunk among 4-6-year-old children of both sexes and environments}

\author{
Mirosław Mrozkowiak ${ }^{\bowtie}$ \\ 1 Uniwersytet Kazimierza Wielkiego w Bydgoszczy, Instytut Kultury Fizycznej, Zdrowia i Turystyki, ul. Sportowa 2, 85-091 Bydgoszcz \\ Kazimierz Wielki University in Bydgoszcz, Institute of Physical Culture, Health and Tourism \\ $\triangle$ magmar54@interia.pl
}

\begin{abstract}
Introduction: The purpose of the research is to demonstrate the frequency of significant relationships between body weight and height and selected parameters of trunk.

Materials and methods: The study was conducted among children aged 4-6 years during the period of 3 years, in 6 half-year intervals and enabled the recording of 2,988 observations of 41 parameters of trunk, weight and height of the body. The photogrammetric method, relying on projection-type moire photography, was applied to measure the selected parameters.

Results: The frequency of significant relationships between body height and body parameters was $21.42 \%$, and body weight $14.28 \%$. The prevalence of significant relationships regarding body height was $14.28 \%$ for sex and $4.76 \%$ for body weight (for girls, $7.14 \%$ and $9.52 \%$ respectively).

Conclusions: 1. Among 4-6-year-old children, body height is significantly more frequently related to the parameters of trunk
\end{abstract}

than body weight, and the parameters mainly concern the sagittal plane. There is no significantly frequent relationship between trunk parameters and body weight and height. 2. Among boys, body height is significantly more frequently related to the parameters of trunk than weight. Among girls, the frequency of these relationships is similar and at a lower level. As regards children from rural areas, body height is more frequently related with the parameters of trunk than body weight, whereas in urban areas body weight is more frequently related with trunk parameters. 3. The most frequent relationships between body height and trunk parameters are reported in boys living in rural areas, and are not observed in towns and cities. The relationships of body weight are sporadic. Among girls living in towns and villages, the frequency of these relationships is at a low and stable level. However, the frequency of relationships of body height is lowest in urban areas.

Keywords: body weight and height; parameters of body posture.

\begin{abstract}
ABSTRAKT
Wstęp: Celem badań było wykazanie częstości istotnych związków masy i wysokości ciała z wybranymi cechami tułowia.

Materiały i metody: Badania wśród dzieci w wieku 4-6 lat zostały przeprowadzone w okresie 3 lat, w 6 półrocznych edycjach, co pozwoliło zarejestrować 2988 obserwacji wielkości 41 cech opisujących tułów, masę i wysokość ciała. Do pomiaru wybranych cech zastosowano metodę fotogrametryczną wykorzystującą zjawisko mory projekcyjnej.

Wyniki: Częstość istotnych związków wysokości ciała z cechami postawy ciała wynosi $21,42 \%$, a masy ciała $-14,28 \%$. Częstość istotnych związków wysokości ciała w ramach płci kształtuje się na poziomie $14,28 \%$, a masy ciała $-4,76 \%$, wśród dziewcząt odpowiednio: 7,14\% i 9,52\%.

Wnioski: 1. Wśród 4-6-letnich dzieci wysokość ciała wykazuje znacząco częstszy związek z cechami tułowia niż masa ciała
\end{abstract}

i są to głównie cechy płaszczyzny strzałkowej. Masa i wysokość ciała nie wykazują szczególnie częstego związku z cechami tułowia. 2. Wśród chłopców wysokość ciała wykazuje znacząco częstszy istotny związek z cechami tułowia niż masa ciała. Wśród dziewcząt częstość tych związków jest zbliżona i na niższym poziomie. Wśród dzieci mieszkających na wsi wysokość ciała wykazuje częstsze związki z cechami tułowia niż masa ciała, natomiast w mieście to masa ciała ma częstsze związki z cechami tułowia. 3. Wśród chłopców najczęstsze istotne związki wysokości ciała z cechami tułowia występują u mieszkających na wsi, natomiast w mieście nie występują. Związki masy ciała są sporadyczne. Wśród dziewcząt mieszkających w mieście i na wsi częstość tych związków jest na niskim i wyrównanym poziomie, przy czym częstość związków wysokości ciała w mieście jest najniższa.

Słowa kluczowe: masa i wysokość ciała; cechy postawy ciała.

\section{WSTĘP}

Z przeglądu piśmiennictwa dotyczącego tematu wynika, że problem podejmowany jest sporadycznie. Autorzy bardziej skupiają się na związkach masy ciała z budową stóp niż

masy i wysokości ciała z cechami postawy w obrębie tułowia. Do rzadkości należą prace dotyczące dzieci w wieku przedszkolnym, a jest to także istotny etap posturogenezy. To czas bezpośrednio poprzedzający rozpoczęcie nowego etapu szkolnego. W okresie tym występuje intensywne zwiększanie 
wysokości ciała, zmiana proporcji ciała oraz wielkości kątowych i liniowych fizjologicznych krzywizn kręgosłupa. Jednym z czynników warunkujących jakość postawy ciała jest budowa somatyczna [1]. Wojna i wsp. wykazali, że w grupie 105 badanych dzieci w wieku przedszkolnym częściej występowały postawy nieprawidłowe niż prawidłowe. Autorzy przyczynę upatrują w różnej dynamice rozwoju posturogenezy zależnej m.in. od płci i rozwoju somatycznego. Wśród dziewcząt o postawie prawidłowej dominowała średnia budowa ciała, a o nieprawidłowej - smukła i masywna. Natomiast wśród chłopców o postawie zarówno prawidłowej, jak i nieprawidłowej - masywna budowa ciała [2]. Badania Makris i Umiastowskiej oraz Demczuk-Włodarczyk [3, 4], a także wcześniejsze badania własne [5] zdają się podzielać wniosek, że dynamika progresji masy i wysokości ciała w tym wieku jest zróżnicowana. Chłopcy przy masie ciała zbliżonej do dziewcząt są wyżsi średnio o 2-3 cm, przy czym wg cytowanych autorów charakteryzują się bardziej harmonijnym rozwojem niż dziewczęta.

Celem badań było wykazanie częstości istotnych związków masy i wysokości ciała z wybranymi cechami postawy ciała w obrębie tułowia wśród 4-6-letnich dzieci. Analiza wyników badań zmierzała w czterech kierunkach. Pierwszy to odpowiedź na pytanie: Z którymi cechami tułowia, miednicy i kręgosłupa najczęściej wykazują istotny związek masa i wysokość ciała w wieku 4-6 lat? Drugi i trzeci to odpowiedź na pytanie: Z którymi cechami najczęściej wykazują istotny związek w ramach dymorfizmu płciowego i środowiskowego? Czwarty to odpowiedź na pytanie: Jaka jest częstotliwość istotnych związków masy oraz wysokości ciała wśród dziewcząt i chłopców w ramach każdego ze środowisk?

\section{MATERIAŁY I METODY}

Badania wśród dzieci w wieku 4-6 lat zostały przeprowadzone w okresie 3 lat, w 6 półrocznych edycjach, co pozwoliło zarejestrować 2988 obserwacji u 1482 dziewcząt i 1506 chłopców. Do analizy statystycznej wybrano masę i wysokość ciała oraz 41 kątowych i liniowych parametrów kręgosłupa, miednicy i tułowia w płaszczyźnie strzałkowej, czołowej i poprzecznej, w poszczególnych kategoriach wiekowych, płci, a także środowiska (tab. 1). Ze względu na ograniczoną objętość pracy dokładny opis cech somatycznych materiału badawczego i uzyskanych wyników badań dociekliwy czytelnik znajdzie w monografii autora [5].

Podstawowym założeniem w badaniach było to, aby ocenie podlegała zawsze postawa habitualna, jako względnie trwała właściwość osobnicza człowieka. Postawa ta odzwierciedla indywidualny stan emocjonalny, psychiczny, społeczny i socjalny badanego. Najrzetelniej opisuje jego sylwetkę w czasie i miejscu. Przeprowadzona diagnostyka nie określa, czy postawa osobnika jest prawidłowa, stwierdza jedynie jaki jest stan jej realizacji ontogenetycznej. Zobiektywizowane i porównywalne wyniki badań umożliwią zarejestrowanie przyjętych do analizy parametrów z możliwymi do określenia kompensacjami. Połączenie badania tułowia i stóp pozwala obiektywnie określić jakość wzorca postawy realizowanego w danym środowisku, płci i kategorii wiekowej. Zastosowane urządzenie pomiarowe określa kilkadziesiąt parametrów opisujących postawę ciała. Uzyskanie przestrzennego obrazu możliwe jest dzięki wyświetleniu na plecach dziecka linii o ściśle określonych parametrach. Linie, padając na skórę, ulegają zniekształceniom zależnie od konfiguracji powierzchni. Dzięki zastosowaniu obiektywu obraz badanego może być odebrany przez specjalny układ optyczny z kamerą, a następnie przekazany na monitor komputera. Zniekształcenia obrazu linii rejestrowane w pamięci komputera algorytm numeryczny przetwarza na mapę warstwicową badanej powierzchni. Podczas badania należy zdawać sobie sprawę z tego, że wykonane zdjęcie rejestruje obraz sylwetki widocznej na skórze dziecka [5].

Dane empiryczne były cechami ilościowymi i jakościowymi (płeć, miejsce zamieszkania itp.). Dokonano obliczeń wartości statystyk pozycyjnych (średnia arytmetyczna, kwartyle), parametru rozproszenia (odchylenie standardowe) oraz wskaźników symetrii (współczynników asymetrii i skupienia) dających pełny ogląd dotyczący rozkładu badanych cech przy uwzględnieniu grup wiekowych, płci i środowiska. Związki i istotność określono, stosując p-value oraz częstość w formie procentowej.

\section{WYNIKI}

Masa ciała wykazuje istotny związek z następującymi cechami: lewostronnym uwypukleniem linii wyrostków kolczystych kręgosłupa, lokalizacją kręgu maksymalnie odchylonego w tej asymetrii, kątem prawostronnego skręcenia miednicy, asymetrią oddalenia kątów dolnych łopatek od linii wyrostków kręgów, gdzie lewy kąt jest bardziej oddalony, kątem nachylenia odcinka piersiowego górnego kręgosłupa i kątem kifozy piersiowej, a wysokość ciała z: kątem lewostronnego nachylenia miednicy, kątem nachylenia odcinka piersiowo-lędźwiowego kręgosłupa, długością, głębokością i kątem lordozy lędźwiowej, kątem i głębokością kifozy piersiowej, lewostronnym uwypukleniem linii wyrostków kolczystych kręgosłupa.

Z analizy statystycznej wynika, że wśród 4-6-letnich dzieci częstość istotnych związków wysokości ciała z cechami postawy ciała wynosi 21,42\%, a masy ciała -14,28\%. Wśród chłopców częstość związków dotyczących wysokości ciała kształtuje się na poziomie $14,28 \%$, a masy ciała - 4,76\%. Wśród dziewcząt odpowiednio: 7,14\% i 9,52\%. Profil analizy pod kątem środowiska wykazał, że wśród osobników mieszkających w mieście częstość istotnych związków wysokości ciała z cechami postawy ciała to 2,38\%, a masy ciała - 7,14\%. Wśród mieszkających na wsi odpowiednio 19,04\% i 7,14\% (ryc. 1 i tab. 2).

Dokładniejsze koncypowanie odsetka istotnych związków w ramach środowiska wykazało, że wśród chłopców z miasta wysokość ciała nie ma żadnych związków z cechami płci, a masa ciała tylko 2,38\%, natomiast wśród mieszkających na wsi odpowiednio: 14,28\% i 2,38\%. Częstość istotnych związków wysokości ciała wśród dziewcząt z miasta wynosi 2,38\%, 
TABELA 1. Wykaz rejestrowanych cech tułowia, masy i wysokości ciała

\begin{tabular}{|c|c|c|c|c|}
\hline \multirow{2}{*}{$\mathrm{Nr}$} & \multirow{2}{*}{ Symbol } & \multicolumn{3}{|c|}{ Parametry } \\
\hline & & miano & nazwa & opis \\
\hline \multicolumn{5}{|c|}{ Płaszczyzna strzałkowa } \\
\hline 1 & Alfa & stopnie & nachylenie odcinka lędźwiowo-krzyżowego & \\
\hline 2 & Beta & stopnie & nachylenie odcinka piersiowo-lędźwiowego & \\
\hline 3 & Gamma & stopnie & nachylenie odcinka piersiowego górnego & \\
\hline 4 & DCK & $\mathrm{mm}$ & długość całkowita kręgosłupa & odległość między punktami $\mathrm{C}_{7}$ i $\mathrm{S}_{1}$ mierzona w pionie \\
\hline 5 & KPT & stopnie & kąt wyprostu tułowia & określony jest odchyleniem linii $\mathrm{C}_{7}-\mathrm{S}_{1}$ od pionu (w tyt) \\
\hline 6 & KPT- & stopnie & kąt zgięcia tułowia & określony jest odchyleniem linii $C_{7}-S_{1}$ od pionu (w przód) \\
\hline 7 & DKP & $\mathrm{mm}$ & długość kifozy piersiowej & odległość między punktami LL a $C_{7}$ \\
\hline 8 & KKP & stopnie & kąt kifozy piersiowej & KKP = $180-($ Beta + Gamma $)$ \\
\hline 9 & RKP & $\mathrm{mm}$ & wysokość kifozy piersiowej & odległość między punktami $C_{7}$ a PL \\
\hline 10 & GKP & $\mathrm{mm}$ & głębokość kifozy piersiowej & $\begin{array}{l}\text { odległość mierzona poziomo między liniami pionowymi } \\
\text { przechodzącymi przez punktu PL i KP }\end{array}$ \\
\hline 11 & DLL & $\mathrm{mm}$ & długość lordozy lędźwiowej & odległość między punktami $S_{1}$ a KP \\
\hline 12 & KLL & stopnie & kąt lordozy lędźwiowej & $\mathrm{KLL}=180-($ Alfa + Beta $)$ \\
\hline 13 & RLL & $\mathrm{mm}$ & wysokość lordozy lędźwiowej & odległość między punktami $\mathrm{S}_{1}$ a PL \\
\hline 14 & GLL- & $\mathrm{mm}$ & głębokość lordozy lędźwiowej & $\begin{array}{l}\text { odległość mierzona poziomo między liniami pionowymi } \\
\text { przechodzącymi przez punkty PL i LL }\end{array}$ \\
\hline
\end{tabular}

\begin{tabular}{|c|c|c|c|c|}
\hline \multicolumn{5}{|c|}{ Płaszczyzna czołowa } \\
\hline 15 & KNT- & stopnie & \multirow[t]{2}{*}{ kąt zgięcia tułowia w bok } & określony jest odchyleniem linii $C_{7}-S_{1}$ od pionu w lewo \\
\hline 16 & KNT & stopnie & & określony jest odchyleniem linii $C_{7}-S_{1}$ od pionu w prawo \\
\hline 17 & LBW- & $\mathrm{mm}$ & prawy bark wyżej & \multirow{2}{*}{$\begin{array}{l}\text { odległość mierzona pionowo między liniami poziomymi } \\
\text { przechodzącymi przez punkty } \mathrm{B}_{2} \mathrm{i}_{4}\end{array}$} \\
\hline 18 & LBW & $\mathrm{mm}$ & lewy bark wyżej & \\
\hline 19 & KLB & stopnie & kąt linii barków, prawy wyżej & \multirow{2}{*}{$\begin{array}{l}\text { kąt między linią poziomą a prostą przechodzącą przez punkty } \\
\mathrm{B}_{2} \mathrm{i}_{4}\end{array}$} \\
\hline 20 & KLB- & stopnie & kąt linii barków, lewy wyżej & \\
\hline 21 & LŁW & $\mathrm{mm}$ & lewa łopatka wyżej & \multirow{2}{*}{$\begin{array}{l}\text { odległość mierzona pionowo między liniami poziomymi } \\
\text { przechodzącymi przez punkty } Ł \text { l } \nmid p\end{array}$} \\
\hline 22 & LŁW- & $\mathrm{mm}$ & prawa łopatka wyżej & \\
\hline 23 & UL & stopnie & kąt linii łopatek, prawa wyżej & \multirow{2}{*}{$\begin{array}{l}\text { kąt między linią poziomą a prostą przechodzącą przez punkty } \\
\text { Łl i Łp }\end{array}$} \\
\hline 24 & UL- & stopnie & kąt linii łopatek, lewa wyżej & \\
\hline 25 & $\mathrm{OL}$ & $\mathrm{mm}$ & kąt dolny lewej topatki bardziej oddalony & \multirow{2}{*}{$\begin{array}{l}\text { różnica oddalenia dolnych kątów łopatek od linii wyrostków } \\
\text { kolczystych kręgosłupa mierzona poziomo na prostych } \\
\text { przechodzących przez punkty Łl i Łp }\end{array}$} \\
\hline 26 & OL- & $\mathrm{mm}$ & kąt dolny prawej łopatki bardziej oddalony & \\
\hline 27 & TT & $\mathrm{mm}$ & lewy trójkąt taliowy jest wyższy & \multirow{2}{*}{$\begin{array}{l}\text { różnica odległości mierzona pionowo między punktami } \mathrm{T}_{1} \mathrm{i}_{2} \\
\mathrm{aT}_{3} \mathrm{iT}_{4}\end{array}$} \\
\hline 28 & TT- & $\mathrm{mm}$ & prawy trójkąt taliowy jest wyższy & \\
\hline 29 & TS & $\mathrm{mm}$ & lewy trójkąt taliowy jest szerszy & \multirow{2}{*}{$\begin{array}{l}\text { różnica odległości mierzona poziomo między prostymi } \\
\text { przechodzącymi przez punkty } \mathrm{T}_{1} \mathrm{i}_{2} \text { a } \mathrm{T}_{3} \mathrm{i} \mathrm{T}_{4}\end{array}$} \\
\hline 30 & TS- & $\mathrm{mm}$ & prawy trójkąt taliowy jest szerszy & \\
\hline 31 & KNM & stopnie & $\begin{array}{l}\text { kąt nachylenia miednicy, prawy talerz biodrowy } \\
\text { wyżej }\end{array}$ & \multirow[t]{2}{*}{$\begin{array}{l}\text { kąt między linią poziomą a prostą przechodzącą przez punkty } \\
\text { Ml i Mp }\end{array}$} \\
\hline 32 & KNM- & stopnie & kąt nachylenia miednicy, lewy talerz biodrowy wyżej & \\
\hline 33 & UK & $\mathrm{mm}$ & $\begin{array}{l}\text { maksymalne odchylenie wyrostka kolczystego kręgu } \\
\text { w prawo }\end{array}$ & \multirow{2}{*}{$\begin{array}{l}\text { największe odchylenie wyrostka kolczystego od pionu } \\
\text { wyprowadzonego z S1; odległość mierzona jest w osi } \\
\text { poziomej }\end{array}$} \\
\hline 34 & UK- & $\mathrm{mm}$ & $\begin{array}{l}\text { maksymalne odchylenie wyrostka kolczystego kręgu } \\
\text { w lewo }\end{array}$ & \\
\hline 35 & NK & - & $\begin{array}{l}\text { nr kręgu maksymalnie odchylonego w lewo lub } \\
\text { prawo }\end{array}$ & $\begin{array}{l}\text { numer kręgu najbardziej odchylonego w lewo lub prawo } \\
\text { w asymetrycznym przebiegu linii wyrostków kolczystych, } \\
\text { licząc jako } 1 \text {, pierwszy kręg szyjny }\left(\mathrm{C}_{1}\right) \text {; } \\
\text { jeśli średnia arytmetyczna przyjmuje wartość np. od } 12,0 \\
\text { do } 12,5 \text {, to jest to } \mathrm{Th}_{5} \text {, jeśli od } 12,6 \text { do } 12,9 \text {, to jest to } \mathrm{Th}_{6}\end{array}$ \\
\hline \multicolumn{5}{|c|}{ Płaszczyzna poprzeczna } \\
\hline 36 & ŁB- & $\mathrm{mm}$ & kąt dolny prawej topatki bardziej uwypuklony & \multirow{2}{*}{$\begin{array}{l}\text { różnica odległość dolnych kątów łopatek od powierzchni } \\
\text { pleców }\end{array}$} \\
\hline 37 & $Ł B$ & $\mathrm{~mm}$ & kąt dolny lewej topatki bardziej uwypuklony & \\
\hline
\end{tabular}




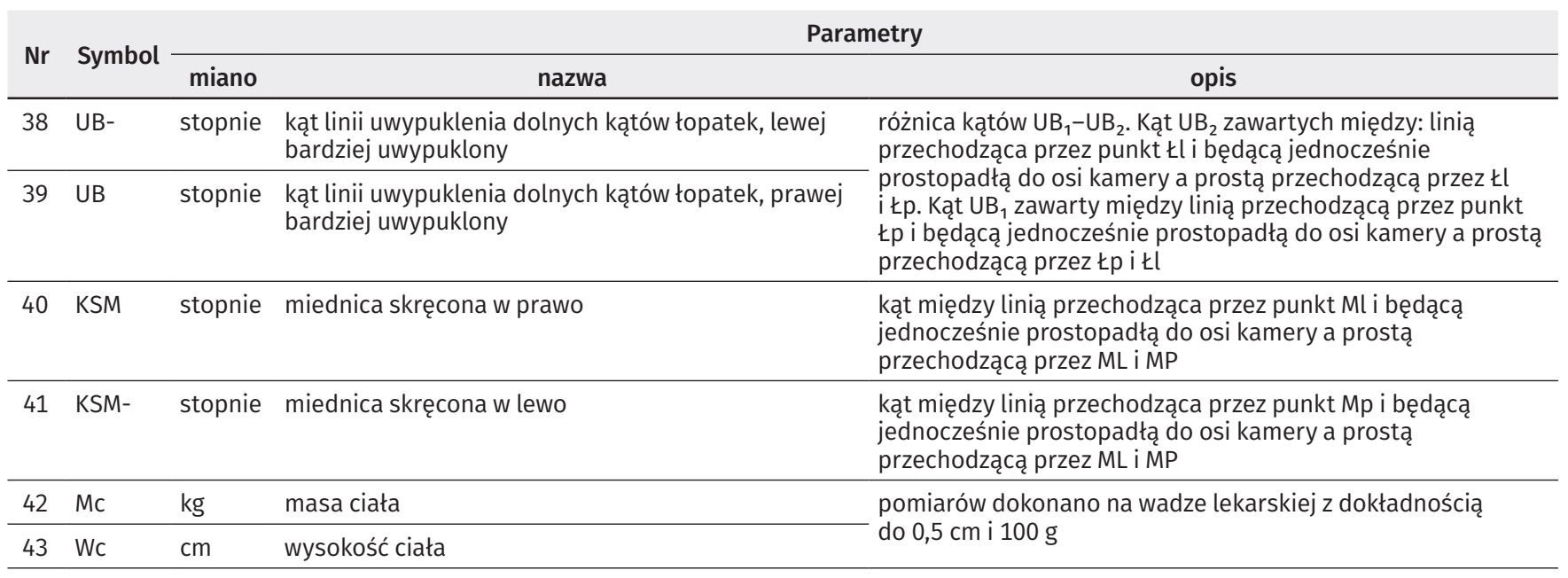

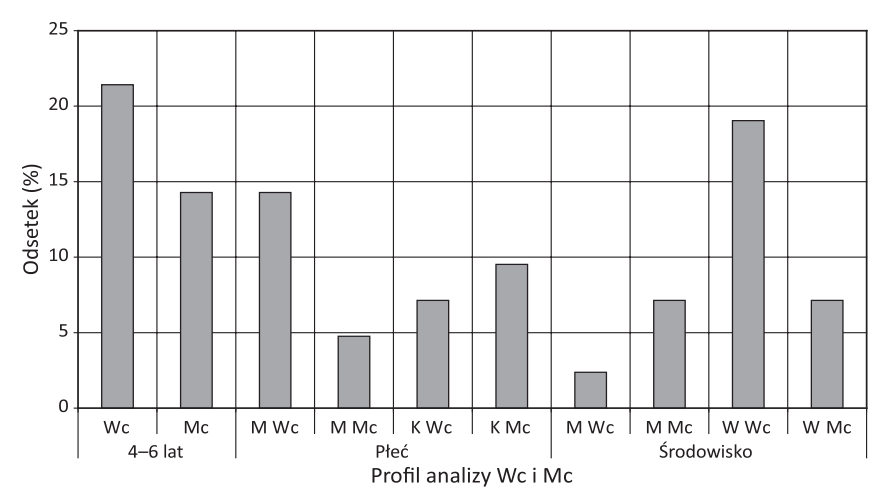

RYCINA 1. Odsetek istotnych związków wysokości i masy ciała z cechami postawy ciała w zależności od przedziału wieku, płci (kobiety - K = 1482; mężczyźni - M = 1506) i środowiska

TABELA 2. Odsetek istotnych związków wysokości i masy ciała z cechami zespołu kręgosłupa - miednicy z podziałem na płeć (kobiety - K = 1482 i mężczyźni - M = 1506) oraz środowisko

\begin{tabular}{llc}
\multicolumn{1}{c}{ Profil analizy } & \multicolumn{1}{c}{ Wysokość i masa ciała } & Odsetek związku \\
\hline W wieku & wysokość ciała & 21,42 \\
\cline { 2 - 3 } 4-6 lat & masa ciała & 14,28 \\
\hline \multirow{2}{*}{ Płeć } & mężczyzna - wysokość ciała & 14,28 \\
\cline { 2 - 3 } & kobieta - wysokość ciała & 4,76 \\
\cline { 2 - 3 } & kobieta - masa ciała & 7,14 \\
\hline \multirow{2}{*}{ Środowisko } & miasto - wysokość ciała & 9,52 \\
\cline { 2 - 3 } & miasto - masa ciała & 7,38 \\
\cline { 2 - 3 } & wieś - wysokość ciała & 7,14 \\
\cline { 2 - 3 } & wieś - masa ciała & 7,14 \\
\hline
\end{tabular}

a masy ciała oraz wysokości i masy ciała dziewcząt ze wsi $4,76 \%$ (ryc. 2 i tab. 3 ).

\section{DYSKUSJA}

W dostępnym piśmiennictwie przedmiotu nie napotkano wyników badań określających częstotliwość istotnych związków

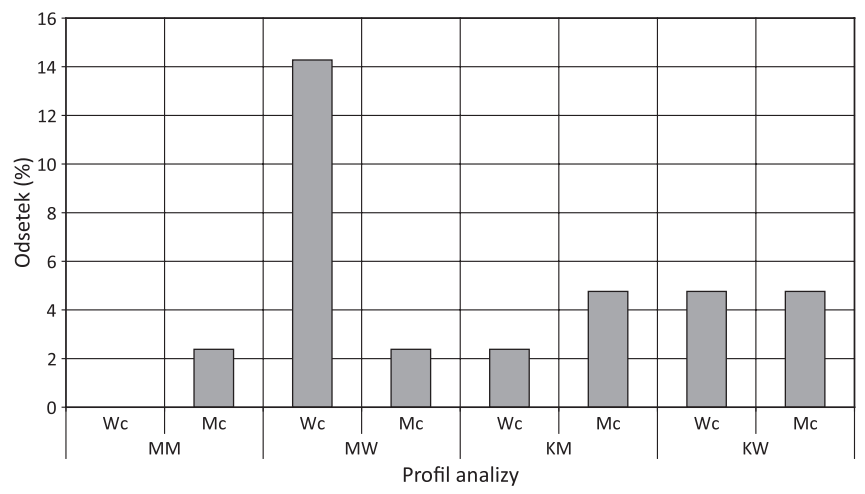

RYCINA 2. Odsetek istotnych związków wysokości i masy ciała z cechami postawy ciała osobników płci męskiej $(M=1506)$ i żeńskiej $(K=1482)$ w zależności od środowiska

TABELA 3. Odsetek istotnych związków wysokości i masy ciała z cechami zespołu kręgosłupa - miednicy osobników ptci męskiej $(M=1506)$ i żeńskiej $(K=1482)$ ze środowiska miejskiego i wiejskiego

\begin{tabular}{llc}
\multicolumn{1}{c}{ Profil analizy } & \multicolumn{1}{c}{ Wysokość i masa ciała } & Odsetek związku \\
\hline \multirow{2}{*}{ Mężczyzna - miasto } & wysokość ciała & 0 \\
\cline { 2 - 3 } & masa ciała & 2,38 \\
\hline \multirow{2}{*}{ Mężczyzna - wieś } & wysokość ciała & 14,28 \\
\cline { 2 - 3 } & masa ciała & 2,38 \\
\hline \multirow{2}{*}{ Kobieta - miasto } & wysokość ciała & 2,38 \\
\cline { 2 - 3 } & masa ciała & 4,76 \\
\hline \multirow{2}{*}{ Kobieta - wieś } & wysokość ciała & 4,76 \\
\cline { 2 - 3 } & masa ciała & 4,76 \\
\hline
\end{tabular}

cech somatycznych z wybranymi cechami tułowia. Autorzy skupiali się raczej na stwierdzeniu związków lub współwystępowania wielkości wysokości i masy ciała z cechami stóp, rzadziej tułowia. Przedstawione zależności są ważne z punktu widzenia toczącej się posturogenezy w obranym przedziale wieku. Powinny zwrócić uwagę rodziców i nauczycieli na niewątpliwie duży wpływ wysokości i masy ciała na cechy postawy w obrębie tułowia, a nie tylko stóp. 


\section{WNIOSKI}

1. Wśród 4-6-letnich dzieci wysokość ciała wykazuje znacząco częstszy związek z cechami tułowia niż masa ciała i są to głównie cechy płaszczyzny strzałkowej. Masa i wysokość ciała nie wykazują szczególnie częstego związku z cechami tułowia.

2. Wśród chłopców wysokość ciała wykazuje znacząco częstszy istotny związek z cechami tułowia niż masa ciała. Wśród dziewcząt częstość tych związków jest zbliżona i na niższym poziomie. Wśród dzieci mieszkających na wsi wysokość ciała wykazuje częstsze związki z cechami tułowia niż masa ciała, natomiast w mieście to masa ciała ma częstsze związki z cechami tułowia.

3. Wśród chłopców najczęstsze istotne związki wysokości ciała z cechami tułowia występują u mieszkających na wsi, natomiast w mieście nie występują. Związki masy ciała są sporadyczne. Wśród dziewcząt mieszkających w mieście i na wsi częstość tych związków jest na niskim i wyrównanym poziomie, przy czym częstość związków wysokości ciała w mieście jest najniższa.

\section{PIŚMIENNICTWO}

1. Ochwanowski P, Janiszewski M. Charakterystyka rozwoju fizycznego dzieci w wieku przedszkolnym. Medycyna Manualna 2003;3-4:27-8.

2. Wojna D, Anwajler J, Hawrylak M. Metoda fotogrametryczna w ocenie budowy i postawy ciała dzieci w wieku przedszkolnym. Acta Bio-Opt Inform Med 2009;15(2):145-8.

3. Makris M, Umiastowska D. Rozwój fizyczny i motoryczny dziecka w wieku przedszkolnym. Szczecin: Wyd. Nauk. Uniwersytetu Szczecińskiego; 2001. p. 53-60.

4. Demczuk-Włodarczyk E. Budowa stopy w okresie rozwoju progresywnego człowieka. Studia i monografie nr 66. Wrocław: AWF; 2003. p. 22-7.

5. Mrozkowiak M. Modulacja, wpływ i związki wybranych parametrów postawy ciała dzieci i młodzieży w wieku od 4 do 18 lat w świetle mory projekcyjnej. Tom 2. Bydgoszcz: Wydawnictwo Uniwersytetu Kazimierza Wielkiego w Bydgoszczy; 2015. 